[Extracted from the Linnean Society's Journal-ZooLogr, Vol. xxxii. No. 212, October 1911.]

The British Museum Collection of Blattid enclosed in Amber. By R. Shelford, M.A., F.L.S.

(Plate 7.)

[Read 4th May, 1911.]

IN a previous number of this Journal (Zool. vol. xxx. 1910, pp. 336-355) I described a large collection of Blattidæ in amber belonging to the late Dr. R. Klebs, of Königsberg-i.-Pr. The memoir here presented deals with a smaller collection which Dr. A. Smith Woodward, F.R.S., has most kindly handed over to me for examination and study. The specimens come from several localities and from at least two geological horizons, and by my study of them I am enabled to extend slightly our knowledge of the cockroaches of the past. The extreme modernity of the species is as apparent in this collection as in that belonging to Dr. Klebs, and again I find it unnecessary to erect a single new genus for the new forms which I describe. For this I was prepared, but I was certainly not prepared to find an example of the modern species Euthyrrhapha pacifica, Coq., in the British Museum collection; and yet such is indeed the case. This species, which at present is found in most of the tropical regions of the world, occurred in Miocene times in Europe, as evidenced by a well-preserved specimen in amber which, after a careful examination, I find to be identical with modern pinned specimens in the Hope Museum, Oxford. If Euthyrrhapha pacifica was a generalised type of cockroach, its occurrence in the Miocene period would perhaps excite but little surprise ; but it is a highly modified form and the type of wing-structure is quite peculiar.

The wide geographical distribution of this speeies is sufficient evidence of its "fitness" to survive amidst divergent conditions of life. Its occurrence in Europe in Miocene times, and in a form which, so far as can be seen, does not differ in any important particular from examples extant to-day in South Africa, shows that the survival-value of the species is no new attribute, but a heritage from a past of very respectable antiquity. Until our knowledge of the 'Tertiary Blattidæ is much more complete than it is at present, it will be impossible to say whether the present distribution of E. pacifica is an extension of a more restricted range in Miocene times, or if the species had a wider distribution then than at present.

LINN. JOURN.-ZOOLOGY, VOL, XXXI, 
The collection under notice may be classified as follows :-

I. Oligocene species from

a. East Prussia

b. Samland

II. Miocene species from Stettin

III. Species from Africa, geological horizon unknown.
2 specimens.

12 specimens.

7 specimens.

9 specimens*.

I have throughout this paper, in order to facilitate reference, quoted the numbers which the individual specimens bear.

\section{OLIGOCENE SPECIES.}

Dr. Klebs's collection must be nearly complete and exhaustive of the Baltic provinces, for not a single British Museum specimen from this region and horizon can be referred to a new species.

\section{a. EAST PRUSSIA.}

Ischnoptera gedanensis, Germ. \& Ber.

Blatta gedanensis, Germar \& Berendt, Organ. Reste in Bernstein, Bd. ii. Abt. 1, p. 33, pl. 4. fig. 4 (1856).

One male, No. I 13762.

Phyllodromia? furcifera, Shelf.

Phyllodromia furcifera, Shelford, Journ. Linn. Soc., Zool. xxx. (1910) p. 346.

One female in a state of such poor preservation that identification is very doubtful. No. I 13763 .

\section{b. SAMLAND.}

Nearly all of these specimens are larvæ, which it is impossible to refer with any degree of certainty to species described from adult forms. Even when the entomologist is dealing with modern species the allocation of larvæ to their adult forms is attended with great difficulty, unless he is aided by careful field-observations and accurate data; it will be readily understood that the difficulty is enormously increased when the material in the entomologist's hands is fossil. Very young larvæ were easily trapped in the resin which flowed from the trees in the Baltic Oligocene forests, but large, powerful adults could free themselves and leave no trace behind. The

* One of the specimens sent to me is a larval Locustid; this, of course, is not included in the above list. 
student of the amber fauna is therefore always conscious that he has before him only the weaker and more fragile forms, which could not escape their living grave.

Eстовius balticus, Germ. \& Ber.

Blatta baltica, Germar \& Berendt, Organ. Reste in Bernstein, Bd. ii. Abt. 1, p. 34, pl. 4. fig. 5 (1856).

One male, quite typical in appearance. No. I 13755.

\section{ISCHNOPTERA sp.}

A mere fragment of the entire insect, consisting of head, pronotum, and front legs only. No. I 13746.

\section{Temnop'teryx klebsi, Shelf. (Plate \%. figs. 3, 4.)}

Temnopteryx klebsi, Shelford, Journ. Linn. Soc., Zool. xxx. (1910) p. 349.

One male, No. I 13756.

I am able to supplement my original description of this species, as the British Museum specimen is in better condition than the type :- Sixth abdominal tergite with the posterior margin sinuate. Seventh to ninth abdominal segments constricted. Subgenital lamina subquadrately produced, with two styles asymmetrically placed, the right situated at the bottom of a deep notch, the left on the margin. Titillator penis extruded, sharply pointed, apex not hooked.

\section{? Nyctibora succinrca, Shelf.}

Nyctibora succinica, Shelford, t. c. p. 350.

To this species I refer with very considerable doubt a larva (No. I 13748), a larval moult (No. I 13754), and a solitary hind-leg (No. I 13757). The larva is considerably smaller than the type, itself described from a larva, and the moult is smaller still. The shortness of the tarsi with their well-developed pulvilli and arolia show that these specimens cannot be referred to any Phyllodromiine genus, nor to any Periplanetine genus known to occur in the amber fauna. Consequently there is a distinct balance of probability in favour of these specimens being young larvæ of Nyctibora succinica, but I fear that my determination of the species can go no further than that. The single hind-leg is not devoid of interest, since it reveals one of the means whereby the remnants of the amber fauna have been preserved. The tarsal claws are entangled in some strands of spider (?) silk; the anterior edge of the femur is ruptured and some torn muscles protrude from the rupture, showing that the leg was forcibly torn from the body probably by the insect's own frantic struggles to free itself. The amber surrounding the 
derelict leg is quite clear and undisturbed, so that the enclosure of the leg in resin was an event ensuing after its entanglement.

\section{? Polyphaga fossilis.}

Polyphaga fossilis, Shelford, Journ. Linn. Soc., Zool. xxx. (1910) p. 351, pl. 48. fig. 21.

One very young larva which can only be identified with great uncertainty. The preservation of the specimen is not good. No. I 13752 .

\section{LARV $\pi$.}

Four specimens, Nos. I 13747, I 13749, I 13750, I 13753, are probably the very young larvæ of a species of Phyllodromia : a fifth example, No. I 13751, is a young larva of one of the Blattæ muticæ ; the insect is much distorted owing to the extrusion of some of the viscera between the thoracic sclerites ; it is possibly identical with the Polyzosteria parvula of Berendt (Ann. Soc. ent. France, vol. v. p. 542, pl. 16. fig. 1, 1836).

\section{MIOCENE SPECIES FROM STETTIN.}

The small number of Miocene specimens debars us from drawing any very valuable conclusions from a comparison of the Oligocene and Miocene Blattidæ in amber, but we may note the following points :-

The genera Ectobius, Ischnoptera, Temnopteryx, Nyctibora, Holocompsa, and Polyphaga are not represented in the collection from Stettin; two genera make their first appearance in the Miocene, Pseudophyllodromia and Euthyrrhapha ; two genera, Phyllodromia and Ceratinoptera, are common to both horizons, but the Miocene species of the former genus are very different from the Oligocene species and present, if possible, even a more modern appearance. Comment has already been passed on the occurrence of the genus Euthyrrhapha in the Miocene fauna.

These British Museum specimens have the surface of the amber blocks reticulated with minute cracks, so that the examination of the enclosed insects is attended with some difficulty, but I hope that I have succeeded in making out all the details of structure which are visible.

\section{Phyllodromia woodwardi, sp. n. (Plate \%. fig. 5.)}

One male, No. 58577 ; one female, No. I 13770.

Flavo-testaceous; eyes rufous; frons with a V-shaped dark macula. Antennæ long and slender, apical joints dark. Pronotum transversely elliptical, anteriorly not covering vertex of head, posteriorly very slightly produced, disc immaculate, lateral margins hyaline. Tegmina and wings barely exceeding apex of abdomen. Tegmina immaculate, moderately broad, the discoidal sectors straight. Wings with mediastinal vein multiramose 
costals few and ramose, ulnar vein ramose. Abdomen beneath immaculate ; subgenital lamina ( $\left.\delta^{\pi}\right)$ symmetrical, posteriorly produced into a small quadrate lobe, the styles being situated in small notches on either side of the lobe, ( $q$ ) semi-orbicular, ample, supra-anal lamina ( $q$ ) projecting slightly beyond the subgenital lamina, its apex triangularly emarginate. Cerci moderately long, banded beneath with fuscous, 11-jointed. Front femora with the anterior margin beneath armed with a complete row of spines, the more distal shorter than the others ; remaining femora moderately armed.

Total length (o $) 12 \mathrm{~mm} .$, ( o ) $15 \mathrm{~mm}$.

The abdomen of the female has been partially devoured by some predatory insect and only a portion of the wings remains beneath the tegmina, which have been displaced. I have much pleasure in naming this species after Dr. A. Smith Woodward, F.R.S.

Phyllodromia Præacursor, sp. n. (Plate \%. figs. 6, 7.)

One male, No. 58505.

Rufo-testaceous. Antennæ fuscous. Pronotum trapezoidal, anteriorly not covering vertex of head, posteriorly scarcely produced, dise with a few obscure dark points. Tegmina and wings considerably exceeding apex of abdomen. Tegmina with minute castaneous points situated on the costal veins, at the base of the radial and ulnar veins, and on some of the ulnar rami ; mediastinal vein simple, radial vein bifurcate near apex, the lower branch ramose, about 12 costals, some of them bifurcate, discoidal sectors oblique, ooth ulnar veins ramose, anal vein impressed. Wings with mediastinal vein bifurcate. Cerci not visible. Subgenital lamina subtrapezoidal, symmetrical, with 2 genital styles. Front femora on anterior margin beneath armed with a few strong spines, which are succeeded distally by minute piliform spines; remaining femora strongly armed; genicular spines long.

Total length $12 \mathrm{~mm}$.

In this specimen the right tegmen is lifted and extends at right angles to the body, so that its venation ean be clearly. seen; unfortunately the underlying wing is almost completely covered by a portion of the left tegmen. The minutely maculate tegmina should enable this species to be readily recognised.

Pseudophyllodromia succinica, sp. n. (Plate \%. fig. 2.)

One example, No. 58615.

Head testaceous, with a narrow fuscous band on the vertex and two on the frons. Antennæ setaceous, rufescent. Pronotum transversely elliptical, testaceous, with two longitudinal fuscous vittæ. Tegmina long and narrow, fuscous, with the costal margin and the veins in the basal half pale testaceous; about 9 costal veins, the last 3 ramose, posterior ulnar vein simple.

Total length $18 \mathrm{~mm}$. 
This is a mere fragment, the abdomen, legs, and ventral thoracic sternites having been destroyed, probably by some predatory insect, but the wingvenation and the type of coloration are eminently characteristic of the South American section of the genus Pseudophyllodromia. In my former paper on Blattidæ preserved in amber, I drew attention to the fact that, if any comparisons at all were possible between the Oligocene amber fauna and a modern tropical fauna, the Neotropical fauna was the only one which presented features of similarity with the European Oligocene fauna. It is, at any rate, noteworthy that amongst these scanty remnants of what was once an extensive Miocene insect fauna occurs a species which has its nearest allies in South America to-day. It is notoriously hazardous to draw conclusions from insufficient data ; I do not therefore seek to establish any theory on the facts just noted, but content myself with recording them, believing fully that one day their real significance will be established.

Ceratimoptera miocenica, sp. $\mathrm{n}$.

One female, No. 58557.

General colour dark castaneous. Pronotum with anterior margin covering vertex of head, posteriorly slightly produced. Scutellum exposed. Tegmina corneous, barely exceeding apex of abdomen; venation mostly indistinct, but anal vein deeply impressed. Abdomen piceous beneath; subgenital lamina semi-orbicular, ample. Cerci not visible. Legs rufous, hind-femora with 6 spines on the anterior margin beneath, 6 or 7 on the posterior margin beneath.

Total length $8 \mathrm{~mm}$.

The unique specimen is enclosed in a large block of amber in which are also embedded, besides several other insects of different orders, shreds and fragments of vegetable tissue; one such fragment conceals most of the ventral surface of the cockroach, and my description of the insect is therefore much shorter than I should like it to be. The strong armature of the hindfemora distinguishes the species from the four Oligocene representatives of the genus, noted or described by me in my former memoir, and to the best of my belief the species is also different from all known modern Ceratinopterce.

\section{? Periplaneta sp.}

One female, No. 58652.

This is a larva and I refrain from giving it a name, as the adult may be found some day, and until that happens the exact generic position of this immature specimen must remain in doubt.

The general colour is pale ochreous, marked symmetrically with castaneous blotches. The supra-anal lamina is trigonal, its apex notched. The cerci 
are long. The femora are moderately armed. The production backwards of the posterior angles of the meso- and metanotum shows that the adult must be a winged form.

Total length $14 \mathrm{~mm}$.

Euthyrrhapha pacifica, Coq.

Blatta pacifica, Coquebert, Icon. Ins. iii. p. 91, pl. 21. fig. 1 (1804).

One example, No. 58535.

The specimen is so enclosed in a block of amber that I am not able to make out much of the underside details, and therefore I cannot determine the sex with accuracy. The pronotum has a yellow spot at each posterior angle and the legs are dark castaneous, in which details the specimen resembles modern South African more than any South American specimens which I have seen.

The present range of the species is South America, Africa (including Madagascar), and Polynesia.

\section{AFRICAN SPECIMENS.}

Unfortunately the geological horizon of these specimens is unknown. I am willing, however, to hazard the opinion that it is much later than the Oligocene period. Only five genera are represented, viz., Anaplecta, Ischnoptera, Phyllodromia, Periplaneta, and Plectoptera *. The first and last of these genera may be considered as very highly evolved forms; their wing-structure is-if I may be pardoned the expression-le dernier cri in Blattid wing-evolution; and though we must exercise the utmost caution in our attempts to determine the duration 'of a species' existence from an examination of its structure alone, nevertheless I believe that the occurrence of such highly-evolved forms as Anaplecta and Plectoptera in amber is slight evidence in favour of presuming quite a late date for the horizon in which the amber is found.

All but one of the specimens are recorded from East Africa : the single exception has merely the label "Africa"; but as this specimen appears to me to be identical with one of the East African examples, I venture to assume that the provenance of all the specimens is the same. It is unfortunate that the exact locality where these specimens were collected is quite unknown.

\section{A.NAPLECTA sp.}

One male, No. I 13769, with label "Africa" ; one female, No. I 13761.

The numerous species of the genus Anaplecta are of small or minute size ; they exhibit a very uniform type of coloration and the form of the terminal

* The determination of the genus Periplaneta is a little doubtful, as is shown later. 
abdominal segments does not greatly vary. Consequently the systematist is compelled to fall back on the venation of the tegmina and wings in his efforts to discriminate between the species; but this resource fails in the case of these particular amber inclusa, for their tegmina are pressed closely to the body and the merest restige of one wing is visible. I see no object, then, in giving a name to a species which may be, for all I can tell to the contrary, identical with some modern representative of this very difficult genus, and which it is impossible to describe in detail. As a matter of fact, these amber specimens look very like rufous specimens of the modern West African Anaplecta cincta, Gerst., but very probably their wing-venation is totally different.

The following is a description of the specimens :-

Rufo-castaneous. Antennæ fuscous, not quite so long as the body. Pronotum transversely elliptical, its lateral margins hyaline. Tegmina with lateral margin in basal half hyaline; discoidal sectors longitudinal. Subgenital lamina ( $\delta$ ) triangular, apex notched, ( $q$ ) semi-orbicular. Cerci testaceous. Legs testaceous, femora weakly armed.

Total length $5 \mathrm{~mm}$.

IsCHNOPTERA PROVISIONALIS, sp. n.

Two females, Nos. I 13764, I 13766.

Rufo-testaceous. Head with vertex not covered by anterior margin of pronotum; a castaneous band between the eyes. Pronotum trapezoidal, posteriorly produced slightly; disc indistinctly marked with castaneous. Tegmina and wings barely exceeding apex of abdomen. Tegmina with radial vein simple, 15-17 costals, 7 longitudinal discoidal sectors. Outer margins of the abdominal sternites and disc of subgenital lamina blotched with castaneous. Subgenital lamina semi-orbicular, ample. Cerci short. Front femora armed on anterior margin beneath with a few long and strong: spines, succeeded distally by shorter spines; remaining femora moderately armed.

Total length 15-16 mm.

This species presents so exactly the facies of those African species of Ischnoptera typified by Ischnoptera bimaculata, Gerst., that I have no hesitation in determining its generic position, even though the truly diagnostic character of the genus afforded by the wing-venation is not visible. I am less satisfied that the species is really distinct from all modern African species of Ischnoptera, and until the male sex is discovered I fear that this must remain uncertain; the females of this group of the genus resemble each other so closely that their separation into species is excessively difficult even when the entomologist has fresh, pinned specimens before him. The 
specific name which I have adopted for this amber-enclosed Blattid indicates the doubt with which I regard its identity.

Phyllodromia inclusa, sp. n. (Plate \%. fig. 8.)

One male, No. 13765.

Pale testaceous. Antennæ longer than the body. Pronotum trapezoidal, anteriorly not covering vertex of head, posteriorly very slightly produced. Tegmina and wings exceeding apex of abdomen, but not by much. Discoidal sectors of tegmina longitudinal. Supra-anal lamina produced, quadrate, exceeding the apex of the subgenital lamina, which has the apex produced into an asymmetrical lobe; only one genital style, the left, visible. Cerci rather short, with 11 visible joints. Front femora armed on anterior margin beneath with 1-2 strong spines, succeeded distally by piliform setæ ; remaining. femora moderately armed.

Total length $12 \mathrm{~mm}$.

\section{Phyllodromia sp.}

One male, No. I 13759.

The block of amber in which the specimen is embedded has been so cut that it is impossible to get anything but a side view of the cockroach, and even this is obscured by the numerous cracks on the surface of the amber. Under these circumstances it would be unwise to describe the species. I can only say that it differs from the other species of the genus described from amber faunas by the prolongation of the left posterior angle of the subgenital lamina into a spiniform process.

Total length $13 \mathrm{~mm}$.

\section{Periplaneta sp. (Plate \%. fig. 1.)}

Three larvæ, Nos. I 13760 (two specimens in one block), I 13767.

These larvæ, the largest of which is not nearly half-grown, look as if they might be the young of Periplaneta australasice, Fab., a modern, cosmopolitan species, but I think that they are not the same. I must, however, confess to ignorance of the very young larvæ of $P$. australasice; if I may judge from the many collections of Blattidæ which have passed through my hands no one has ever taken the trouble to acquire specimens illustrating the stages in the life-history of the species. Even the exact generic determination of this species is very doubtful; it is quite likely that the discovery of the adult will show that it must be referred to Pseudoderopeltis or even to Stylopyga. The figure illustrating the larger of the larvæ is of more value than many words of description, and will perhaps enable other investigators to decide if the species is distinct from $P$. australasice or not. The larvæ are bright ochreous marked with castaneous. 


\section{Plectoptera antiqua, sp. n. (Plate \%. fig. 9.)}

One female, No. I 13758.

Rufo-castaneous. Antennæ elongate, setaceous, fuscous, with the last four or five joints pale. Pronotum transversely elliptical, anteriorly not covering. vertex of head, sides hyaline. Tegmina hyaline; mediastinal vein giving off some incomplete venules towards the outer margin, radial vein simple ; 10-11 rather irregular costals, many of these joined by transverse venules, a few venæ spuriæ between some of the costals and between the discoidal sectors. Apical field of the wings visible. Subgenital lamina small, apex only slightly produced, styles excessively small. Cerci straight, moderate. Legs testaceous; all the femora entirely unarmed beneath.

Total length (excluding the unfolded wing-apex) $5 \mathrm{~mm}$.

By a fortunate accident the apical field of the wing, which in this genus and in Anaplecta is normally doubled over the rest of the wing and hidden under the tegmina, has been unfolded in this specimen and projects far beyond the apex of the tegmina, so that there can be no doubt as to the generic identity of the species. Unfortunately, whoever was responsible for shaping the block of amber in which the insect is embedded, ground one face a fraction too much, with the result that one-third of the dorsal surface of the insect has been destroyed and the complete venation of the tegmina can no longer be observed. This venation is rather singular and the fraction that is visible suffices to discriminate the species from all the modern representatives of the genus.

The following is a list of all the species noted or described in the preceding pages, arranged in their systematic order :-

Subfam.

Ectobiine.

Ectobius balticus, Germ. \& Ber. Anaplecta sp.

Phyllodroninze. Ischnoptera gedanensis, Germ. \& Ber. Oligocene. E. Prussia.

$$
, \quad \text { sp. }
$$

" provisionalis, sp. n.

Phyllodromia ? furcifera, Shelf.

" inclusa, sp. n.

" sp.

" pracursor, sp. n.

"woodwardi, sp. n.

Pseudophyllodromia succinica, sp. $\mathrm{n}$. Ceratinoptera miocenica, sp. $\mathrm{n}$.

Temnopteryx klebsi, Shelf.

Nyctiborinze. P Nyctibora succinica, Shelf.

Blattine.

Periplaneta sp.

Plectopterin ж. Plectoptera antiqua, sp. n.

Corydinnze.
Euthyrrhapha pacifica, Coq.

? Polyphaga fossilis, Shelf.

\section{Geological}

horizon.

Oligocene. Samland.

$$
\text { ? Africa \& E. Africa. }
$$

Samland.

? E. Africa.

Oligocene. E. Prussia.

E. Africa.

s

Miocene. Stettin.

"9

,9

",

Oligocene. Samland.

" $"$

E. Africa.

Miocene. Stettin.

? E. Africa.

Miocene. Stettin.

Oligocene. Samland. 


\section{EXPLANATION OF PLATE 7.}

Fig. 1. Pleriplaneta larva. (No. I 13767.)

2. Pseudophyllodromia succinica, sp. n. (The artist has represented the insect as a little too broad in proportion to its length.)

3. Temnopteryx klebsi, Shelf., ot, apex of abdomen from above.

4. " " " " " " , beneath.

5. Phyllodromia woodwardi, sp. n., o, apex of abdomen from beneath.

6. $\quad$ pracursor, sp. n., right tegmen.

7. " ", $0^{x}$, apex of abdomen from beneath.

8. " " inchusa, sp. n., on, apex of abdomen from beneath.

9. Plectoptera antiqua, sp. n., portion of left tegmen.

N.B.-Figs. 1 and 2 are reproduced from drawings in the Geological Galleries of the Natural History Museum.
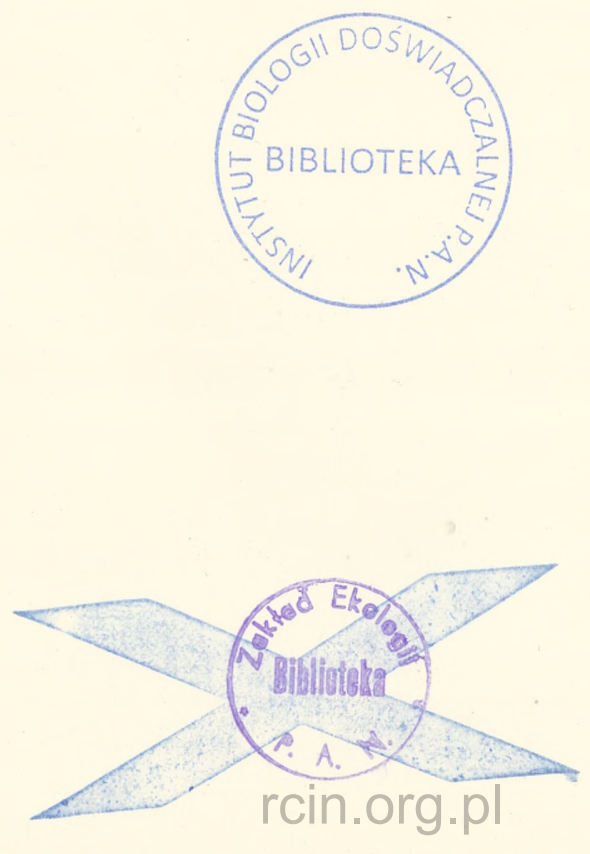
rcin.org.pl 


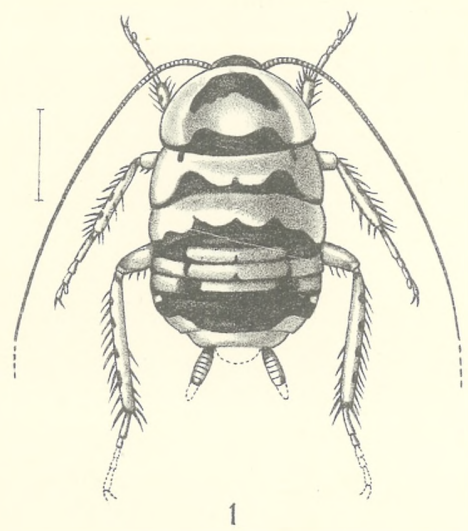

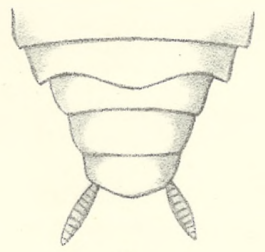

3

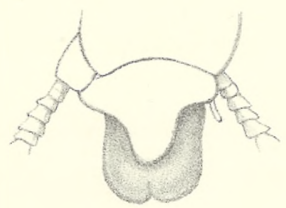

8

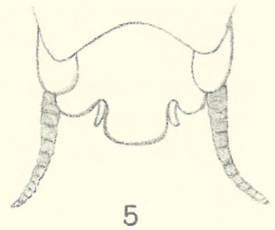

5
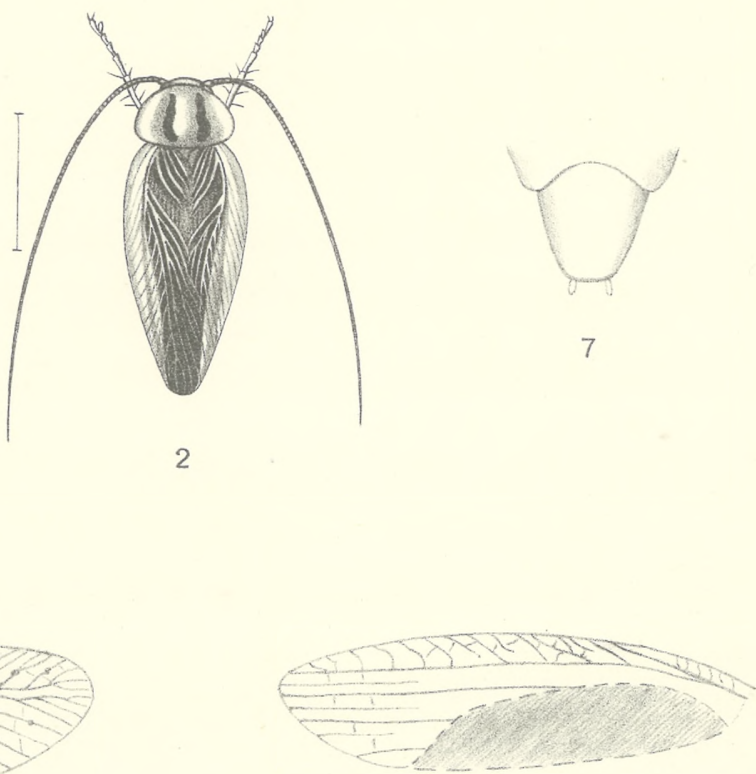

9
H. Knight
et R.S.del.

(Westwood
Bequest.)
BLATTIDAE IN AMBER.

E.Wilson, Cambridge rcin.org.pl 


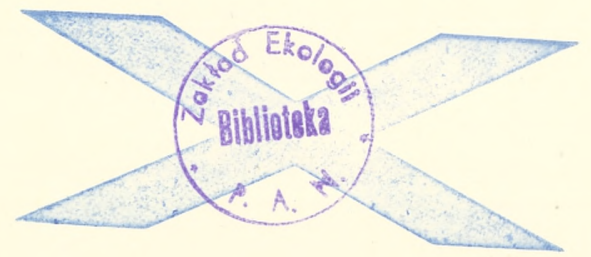

rcin.org.pl 